\title{
Kosher Food Regulation and the Religion Clauses of the First Amendment
}

\author{
Gerald F. Masoudi $\uparrow$
}

The Jewish dietary laws dictate what foods are kosher, or fit for consumption. These laws are mainly spiritual. As one commentator has explained, the "concept [of kosher] is in all truth a hard one to pin down. 'Kosher' is a late Hebrew word that does not occur in the books of Moses. Perhaps the nearest English word is 'fit' in the sense of proper or suitable. But the fitness, it must be clear, is mostly ceremonial."

An estimated ten percent of the nation's six million Jews regularly follow kosher requirements. ${ }^{2}$ Kosher food comprises an almost $\$ 2$ billion-a-year industry, that grew more than twelve percent in $1991 .^{3}$ In 1991, approximately 6,200 firms nationwide produced kosher-certified products. ${ }^{4}$

Despite the spiritual nature of the Jewish dietary laws, many states regulate kosher food to protect consumers against fraud. Kosher food laws generally prohibit the advertisement or sale of any food product labeled "kosher" unless it conforms to state-defined food preparation and handling requirements.

A number of purveyors of kosher food prosecuted under kosher food laws have challenged the laws under the Religion Clauses of the First Amendment. ${ }^{5}$ Such challenges have met mixed success. This Comment analyzes the limitations imposed by the First Amendment on kosher food laws now in force, and proposes a solution for regulating the kosher food industry within those limitations. Section I describes the background of the Jewish dietary

† B.A. 1990, Amherst College; J.D. 1993, The University of Chicago.

1 Herman Wouk, This Is My God 128 (Doubleday, 1959).

2 See Celeste McCall, Market for Kosher Food Growing, Wash Times E2 (Mar 1, 1992).

Id.

- Wilma Randle, Boom-time for Kosher Foods: Many Non-Jews Also Look for the Stamp of Approval, Chi Trib C1 (Apr 12, 1992).

- See Ran-Dav's County Kosher, Inc. v State, 129 NJ 141, 608 A2d 1353 (1992), cert denied as National Jewish Com'n on Law and Public Affairs (COLPA) v Ran-Dav's County Kosher, Inc., 113 S Ct 1366 (1993); Barghout v Mayor \& City Council, 325 Md 311, 600 A2d 841 (1992) (state constitutional challenge); Sossin Systems, Inc. $v$ City of Miami Beach, 262 S2d 28 (Fla App 1972); People v Goldberger, 163 NYS 663 (Sp Sess 1916). 
laws and the scope of the kosher food regulation problem. Section II looks at the extent to which the Supreme Court's Establishment Clause jurisprudence limits the ability of states to regulate kosher foods, and Section III does the same for the Free Exercise Clause. Finally, Section IV proposes a solution to the kosher food regulation problem that surmounts constitutional obstacles.

\section{Kosher Food: The Laws of God and MaN}

\section{A. The Biblical Source}

The Hebrew term kashrut, meaning "fit" or "proper," is "the collective term for the Jewish laws and customs pertaining to the types of food permitted for consumption and their preparation." Because the dietary laws are closely related to holiness in several passages of the Bible, ${ }^{7}$ many scholars believe that the dietary laws were established to promote holiness rather than hygiene. ${ }^{8}$

The particular dietary laws are derived from general rules and enumerations of fit and unfit foods in the Bible. In Genesis, for example, God declares, "Behold, I have given you every herb yielding seed, which is upon the face of all the earth, and every tree." Accordingly, the Jewish dietary laws allow the consumption of fruits and vegetables with little restriction..$^{10}$

The central concerns of the dietary laws are the types of animal life that the adherent may eat, and how the adherent must prepare such food. Those animals considered tahor, or clean, may be consumed if prepared properly; those considered tame, or unclean, may not be consumed under any circumstances. Mammals that have cloven hooves and that chew their cud are generally recognized as clean; all others are considered unclean. ${ }^{11}$

- 6 Encyclopaedia Judaica 26 (Dietary Laws) (Keter Publishing, 1971).

" See Exodus 22:31 (Revised Version) ("And ye shall be holy men unto me; therefore, ye shall not eat any flesh that is torn of beasts in the field; ye shall cast it to the dogs."); Leviticus 11:44 ("For I am the LORD your God: sanctify yourselves therefore, and be ye holy; for I am holy: neither shall ye defile yourselves with any manner of creeping thing that moveth upon the earth."); Deuteronomy 14:21 ("Ye shall not eat of any thing that dieth of itself: thou mayest give it unto the stranger that is within thy gates, that he may eat it; or thou mayest sell it unto a foreigner: for thou art an holy people unto the LoRD thy God.").

${ }^{8}$ See Mircea Eliade, ed, 8 Encyclopedia of Religion 272 (Kashrut) (MacMillan, 1987).

- Genesis 1:29.

10 Some Jews observe a restriction on consuming the fruit of trees during the first three years after their planting. See 12 Encyclopaedia Judaica at 1467 (cited in note 6) (Orlah).

${ }^{11} 6$ Encyclopaedia Judaica at 27 (cited in note 6) (Dietary Laws). 
The Bible also lists unclean birds, of which there are twentyfour, including the eagle and the hawk; ${ }^{12}$ however, it does not give a rule as to how to differentiate between clean and unclean birds. The Mishnah states that "any fowl which seizes is unclean. Any [fowl] which has an extra talon ... and a craw, and the skin of the stomach of which [can] be stripped off is clean."1s

Among fish, those that have "fins and scales in the waters, in the seas, and in the rivers"14 are clean. Among those that are clean are carp, trout and salmon. Among those generally considered unclean are the shark, the catfish and the eel. Aquatic invertebrate life, such as lobster, crab, and shrimp, is categorically unclean. ${ }^{15}$

Aside from dictating what types of animals are clean, the Jewish dietary laws also dictate the proper preparation of these animals. A trained slaughterer ("shohet") must perform ritual slaughter according to a number of precise requirements. For instance, the shohet must use a sharp knife without any nicks or imperfections, and must cut both the esophagus and trachea with continuous strokes. ${ }^{16}$ To achieve the more demanding requirements of glatt kosher, the shohet must examine the slaughtered animal for diseases or imperfections of the vital organs. ${ }^{17}$

An important feature of the Jewish dietary laws is the prohibition against mixing meat with milk. The command " $[t]$ hou shalt not seethe a kid in its mother's milk"18 gives rise to three prohibitions: "cooking meat and milk together; eating such mixture; and deriving any benefit from such a mixture."19 A product which is pareve contains neither milk nor meat, and thus is fit to eat with either milk or meat.

In order to comply with these prohibitions, the adherent must use separate utensils for milk products and meat products, and must wash and store the utensils separately. Not only may the adherent not eat milk and meat at the same meal; she must ensure a period of up to six hours between eating milk and meat.

12 Id.

13 Hul 3:6 in Jacob Neusner, trans, The Mishnah, A New Translation (Yale, 1988).

14 Leviticus 11:9. See also Deuteronomy 14:9.

${ }^{15} 6$ Encyclopaedia Judaica at 37-38 (cited in note 6) (Dietary Laws).

${ }^{18}$ For the five requirements of ritual slaughter, see Yacov Lipschutz, Kashruth 19-21 (Mesorah Publications, 1988).

${ }_{17}$ See id at 22-23.

18 Exodus 23:19.

10 6 Encyclopaedia Judaica at 40 (cited in note 6) (Dietary Laws). 
The book of Ezekiel equates the eating of blood with the sins of murder and idolatry.$^{20}$ From the command against the consumption of blood ${ }^{21}$ comes the prohibition against eating any non-veinal blood in meat. The koshering process achieves fitness by drawing out blood through soaking and salting meat, or roasting it over an open flame.

\section{B. Controversies Over the Jewish Dietary Laws}

Although a considerable body of the dietary law is uncontroverted among the Jews, there is disagreement over the interpretation of some of the dietary prohibitions. This Section outlines a few of the more central disputes among Jews about the laws of kashrut.

Many disputes center on the types of animals that are clean. For example, the modern view is that "only those birds for which there is a tradition that they are clean are permitted."22 On occasion, however, there is a difference of tradition. Whereas some communities regard the pheasant or quail as clean, others do not. Although most modern communities recognize the turkey as clean, as recently as a few generations ago it was not so recognized. Even today, "the descendants of Isaiah Horowitz (the 'Selah') do not eat turkey." "23 With respect to fish, the conservative American rabbinate has ruled that both sturgeon and swordfish are kosher; the Orthodox view is to the contrary. ${ }^{24}$

The prohibition on mixing milk and meat has also been the subject of disagreement. There is a difference of opinion as to how long one must wait between eating milk and meat. The strictest view requires at least six hours between the two. However, "[m]ost West European Jews wait three hours, whereas the Dutch custom is to wait one hour."25 Jews also disagree about hard cheeses. Because some cheeses are made with a curdling agent from the walls of a calf's stomach, some Jews view the cheese as a prohibited mixLaws).

${ }^{20}$ See Ezekiel 33:25. See also 6 Encyclopaedia Judaica at 28 (cited in note 6) (Dietary

21 Leviticus 7:26-27, 17:10-14.

${ }^{22} 6$ Encyclopaedia Judaica at 27 (cited in note 6) (Dietary Laws).

${ }^{23}$ Id at 34. For a biographical sketch of Isaiah Horowitz, see 8 Encyclopaedia Judaica at 990 (cited in note 6) (Horowitz, Isaiah Ben Abraham Ha-Levi).

2. See James M. Lebeau, The Jewish Dietary Laws: Sanctify Life 53 (United Synagogue Youth, 1983); 6 Encyclopaedia Judaica at 27 (cited in note 6) (Dietary Laws).

${ }^{25} 6$ Encyclopaedia Judaica at 40 (cited in note 6) (Dietary Laws). 
ture of milk and meat. Others believe that all cheeses, hard and soft, are kosher. ${ }^{26}$

Orthodox and Conservative Jews also disagree about the requirements of wine preparation. On the Orthodox view, Jews are forbidden to drink wine prepared by a non-Jew: "The interdiction against the drinking of non-Jewish wine is so severe, that even if a gentile merely touches wine prepared by a Jew it is still prohibited, unless the bottle was securely corked and sealed." ${ }^{27}$ However, only the Orthodox observe these strict prohibitions. In the United States, the Rabbinical Assembly of the Conservative movement requires the Orthodox standard only for the wine used during religious ceremonies. ${ }^{28}$

Finally, there is disagreement about the necessity of the benediction that ordinarily precedes slaughtering an animal. "One authority has ruled that the absence of the benediction renders the meat non-kosher but the general opinion is that although a benediction should be recited its omission ... does not affect the validity of the act." ${ }^{\prime 29}$

\section{Kosher Food Laws}

New York enacted the first kosher food law in 1915 in response to the "chaotic state of the kosher food industry-its charlatans, profiteers and outright crooks-which, coupled with the huge influx of immigrants who were unfamiliar with local circumstances, made any assurance of kashruth all but impossible."so The New York statute describes kosher food as that "prepared in accordance with the orthodox Hebrew religious requirements." 1 Soon after their enactment, the New York laws were challenged in People $v$ Goldberger ${ }^{32}$ as a violation of the religious liberties guaranteed by the New York Constitution. The court there quickly dismissed the challenge:

${ }^{26}$ See Lebeau, The Jewish Dietary Laws at 135 (cited in note 24).

2716 Encyclopaedia Judaica at 540 (cited in note 6) (Wine).

28 See id.

29 14 Encyclopaedia Judaica at 1338 (cited in note 6) (Shehitah).

${ }^{30}$ Marc D. Stern, Kosher Food and the Law, 39 Judaism 389 (1990). Stern cites Moses Weinberger, Ha-Yehudim Ve-ha-Yahadut B'New York 13, published in Hebrew in 1887 by the Machzike Talmud Thora Society in New York. For an English translation, see Jonathan D. Sarna, ed \& trans, People Walk on Their Heads: Moses Weinberger's Jews and Judaism in New York 46-50 (Holmes \& Meier, 1982).

31 See NY Agriculture and Markets Law § 201-a (McKinney 1991).

32 I63 NYS 663 (Sp Sess 1916). 
There is no invasion here of religious freedom or personal rights. The statute is directed against a form of fraud, the victim of which is probably only a person belonging to a particular religious order; but such protection, instead of being contrary to the constitutional provision which forbids the interference with the free exercise and enjoyment of religious profession and worship, is in distinct accord therewith. ... Such protection is the evident aim of the statute which occasions this discussion. ${ }^{33}$

Kosher food fraud has remained a significant problem in New York. Between 1985 and 1988, for example, over 240 kosher food violations were referred to the New York Attorney General. ${ }^{34}$

Since the passage of the New York law, a number of states have adopted some form of kosher food regulation. ${ }^{36} \mathrm{Kosher}$ food laws fall generally into two categories. In the first category are the New Jersey regulations which, like the New York statute and those of many states, define "kosher" as prepared in adherence with the strict requirements of the Orthodox Jewish sect. ${ }^{36}$ The New Jersey regulations prohibit the "display of the word 'kosher' in English or Hebrew letters, or by display of any sign, emblem, insignia, sixpointed star, symbol or mark in simulation of the word Kosher" on any food product that is not kosher according to the statute's definition. ${ }^{37}$ The regulations also prohibit the use of the terms "kosher-type," "kosher-style," "Hebrew," or other such terms without a disclaimer that the food is not prepared or kept in adherence to the Orthodox Jewish laws. ${ }^{38}$

In the second category are those laws that define "kosher" without explicit reference to a particular sect of Judaism. For ex-

s3 Id at 666 .

3t Brief of amicus curiae Robert Abrams, Attorney General of the State of New York, in Ran-Dav's County Kosher, Inc. v State, 129 NJ 141, 608 A2d 1353 (1992) (on file with U Chi L Rev).

35 For a listing of states with kosher food laws, see Daniel J. Elezar and Stephen R. Goldstein, The Legal Status of the American Jewish Community, in American Jewish Year Book 1972 1, 35 n 13 (American Jewish Committee and Jewish Pub Society of America, 1972).

ss See NJ Admin Code 13:45A-21.1 (1990) ("Kosher' means a kosher food or food product which is prepared and maintained in strict compliance with the laws and customs of the Orthodox Jewish religion."). For similar approaches, see also La Rev Stat Ann 40:608.2(B) (West 1992); Mo Ann Stat $\S 196.165$ (Vernon 1983); Ohio Rev Code Ann $\S$ 1329.29(A)(4) (Baldwin 1992); Tex Bus and Comm Code Ann § 17.821(1) (Vernon 1987); Wis Stat Ann § 97.56(1) (West 1990).

${ }^{37} \mathrm{NJ}$ Admin Code at 13:45A-21.2(a)(2).

s8 Id at 13:45A-21.2(a)(4). 
ample, Arizona law defines "kosher" as "prepared under the traditional Hebrew rules and requirements or dietary laws."39

What all of the state laws have in common is that they attempt to define the religious term "kosher," and then prohibit the use of this term or any synonymous term unless the advertised product conforms to the definition. The statutes, in keeping with common law formulations of fraud, generally require a specific intent to defraud the consumer. ${ }^{40}$ Some states also delegate the interpretation of the defined term to a rabbi or a council of rabbis.11 Through kosher food laws, some states have created councils of rabbis as advisory bodies; others have gone so far as to hire ordained rabbis to carry out duties of inspection, investigation, and enforcement.

Federal law does little to address kosher food fraud. The Food and Drug Administration has promulgated regulations that dictate that " $[t]$ he term 'kosher' should be used only on food products that meet certain religious dietary requirements." ${ }^{2}$ However, the FDA does not define what the religious requirements are, or enumerate any handling or preparation requirements for kosher food.

State courts have heard a number of challenges to kosher food laws, principally under the Religion Clauses of the First Amendment. Such challenges have been mounted on the grounds that the laws constitute an unconstitutional denominational preference in favor of the Orthodox sect, that the laws impermissibly entangle government and religion, and that the laws infringe upon the free exercise of religion by defining an inherently religious term and requiring purveyors of kosher food to observe that definition. State governments have responded that their kosher food regulations are a justified means of protecting consumers from spurious claims about kosher foods: because kosher food commands a substantially higher price than non-kosher food, there are significant incentives to misrepresent non-kosher food as kosher. The Supreme Court has considered the constitutionality of kosher food laws only under

30 Ariz Rev Stat Ann § 36-941(1) (West 1986).

${ }^{6}$ See, for example, Cal Penal Code $\S 383 b$ (West 1988).

11 See Ran-Dav's, 608 A2d at 1357 (describing State Kosher Advisory Committee composed of ten rabbis); Glickman v Glasner, 230 Cal App 2d 120, 40 Cal Rptr 719, 721-22 n 2 (1964) (describing State Personnel Board specifications for Kosher Food Law Representative, including a requirement that the Representative be an ordained Orthodox rabbi).

1221 CFR § 101.29 (1992). 
the Commerce Clause..$^{43}$ Only one state court has overturned a kosher food law on a constitutional challenge. ${ }^{44}$

The following sections evaluate the merits of these constitutional challenges. This Comment argues that laws that expressly favor the Orthodox interpretation over other understandings of kosher violate the Establishment Clause's flat prohibition on denominational preferences. While the second category of state laws-those which simply require merchants of kosher foods to prepare their food in accordance with "traditional Hebrew standards"-may survive the initial hurdle of denominational preference, the laws are nonetheless constitutionally invalid under the Court's traditional three-pronged Establishment Clause test. This Comment further argues that both types of statutory regime unconstitutionally interfere with the Free Exercise of religion.

\section{Establishment}

The Establishment Clause of the First Amendment provides that "Congress shall make no law respecting an establishment of religion." "Th The Supreme Court has said that "[t]he clearest command of the Establishment Clause is that one religious denomination cannot be officially preferred over another." also noted that denominational preferences implicate the Free Exercise Clause: "freedom for all religion being guaranteed by free competition between religions ... would be impossible in an atmosphere of denominational preference."47 The Court has continued unwaveringly upon this line: "Whatever else the Establishment Clause may mean ... it certainly means at the very least that government may not demonstrate a particular preference for one particular sect or creed." $" 48$

In Establishment Clause cases, the Court's approach has been to look first for facial denominational preference: "when it is claimed that a denominational preference exists, the initial inquiry is whether the law facially differentiates among religions." ${ }^{49}$ In the absence of a denominational preference, the Court "appl[ies] the

4s See Hygrade Provision Co. $v$ Sherman, 266 US 497 (1925). The Religion Clauses did not apply to the states until Cantwell $v$ Connecticut, 310 US 296, 303 (1940).

14 See Ran-Dav's, 608 A2d at 1366-67.

45 US Const, Amend I.

4 Larson $v$ Valente, 456 US 228, 244 (1982).

47 Id at 245.

${ }^{4}$ County of Allegheny $v$ ACLU, 492 US 573, 604 (1989).

19 Hernandez $v$ Commissioner of Internal Revenue, 490 US 680, 695 (1989). 
customary three-pronged Establishment Clause inquiry derived from Lemon $v$ Kurtzman."

\section{A. Denominational Preference}

In Larson $v$ Valente, ${ }^{\text {s1 }}$ the Court considered a statute that exempted religious organizations from a series of burdensome registration requirements imposed on charitable organizations. The statutory regime exempted those organizations that collected over half of all donations from members or affiliated organizations. This provision exempted well-established churches, and burdened newer churches and churches that relied on public solicitation. ${ }^{52}$ Because the exemptions were generally available only to well-established churches, the Court found that the statute created a denominational preference. ${ }^{5 s}$ The Court held that "when we are presented with a state law granting a denominational preference, our precedents demand that we treat the law as suspect and that we apply strict scrutiny in adjudging its constitutionality." "64 Under strict scrutiny, the law in question "must be invalidated unless it is justified by a compelling governmental interest, and unless it is closely fitted to further that interest." rowly tailored to the government interest of protecting citizens from abusive solicitation practices, the Court overturned the state registration scheme. ${ }^{\mathrm{sB}}$

Because strict scrutiny is almost always fatal to government action, litigation usually centers on the issue of classification as denominational preference rather than the issue of whether an action can survive strict scrutiny. Since Larson, the Supreme Court has not considered whether any particular government action creating a denominational preference can survive strict scrutiny. Lower courts, however, have considered strict scrutiny of a denominational preference. In Wilson $v$ NLRB, ${ }^{57}$ the Sixth Circuit considered a denominational preference challenge to the religious objector provision of the National Labor Relations Act (NLRA). ${ }^{68}$ The NLRA provided an exemption from union membership for any em-

so Id.

61456 US 228 (1982).

s2 Id at $247 \mathrm{n} 23$.

ss Id at 246.

s. Id.

ss Id at 247 (citation omitted).

s. Id at 254-55.

87 920 F2d 1282 (6th Cir 1990), cert denied, 112 S Ct 3025 (1992).

ss 29 USC §§ 151 et seq (1988). 
ployee "who is a member of and adheres to established and traditional tenets or teachings of a bona fide religion, body, or sect which has historically held conscientious objections to joining or financially supporting labor organizations." described particular "bona fide" religions with certain traditional beliefs, the court reasoned, the statute created "a denominational preference by conferring a benefit on members of the religious organizations described in the statute." scrutiny, and concluded that the religious objector provision must be overturned because the government had not identified any compelling public interest furthered by the provision. In addition, the court noted that even if the government's ostensible interest-protecting religious freedom in the workplace-were compelling, the statute was not narrowly tailored to serve that interest. Since it "could be more closely fitted to further this interest by paralleling the protection afforded by Title VII, which is without regard to membership in a particular religious organization," the statute did not survive strict scrutiny. ${ }^{61}$

The New Jersey kosher food regulations starkly illustrate a facial denominational preference. New Jersey's regulations make it an unlawful consumer practice to sell or offer for sale "any food or food product which is falsely represented to be kosher, Kosher for Passover, under rabbinical supervision, pareve or as having been prepared under and/or with a product sanctioned by Orthodox Jewish religious requirements." ${ }^{2}$ The statute defines "kosher" as "prepared and maintained in strict compliance with the laws and customs of the Orthodox Jewish religion."

A number of courts have heard challenges to laws similar to the New Jersey law. Yet neither of the two state courts that recently have addressed the Establishment Clause and this type of

s9 29 USC § 169.

6o Wilson, $920 \mathrm{~F} 2 \mathrm{~d}$ at 1287.

o1 Id. Although strict scrutiny is the general rule for denominational preference, a line of cases involving Indian tribes merely required a rational relation. See Rupert $v$ United States Fish and Wildlife Service, 957 F2d 32 (1st Cir 1992). Noting that Congress has "plenary power . . . based on a history of treaties and the assumption of a 'guardian-ward' status, to legislate on behalf of federally recognized Indian tribes," id at 34 (citation omitted), the court rejected the use of the traditional strict scrutiny standard, and instead applied the more lenient rational basis standard to the denominational preference. Id at 35 . See also Peyote Way Church of God v Thornburgh, 922 F2d 1210, 1217 (5th Cir 1991) ("The unique guardian-ward relationship between the federal government and Native American tribes precludes the degree of separation of church and state ordinarily required by the First Amendment.").

e2 NJ Admin Code 13:45A-21.2.

is Id at 13:45A-21.1. 
kosher food law has found a denominational preference. In RanDav's County Kosher, Inc. $v$ State, ${ }^{64}$ the court overturned New Jersey's kosher food regulations based on an Establishment Clause challenge under the Lemon test, but did not address a denominational preference argument. And in Barghout $v$ Mayor \& City Council ${ }^{65}$ the court rejected a denominational preference challenge under the Maryland Constitution to a law that defined "kosher" similarly to the New Jersey law.

In Barghout, the Maryland Court of Appeals reasoned that "kosher" means "fit according to Orthodox principles, not according to the standards of any other system of belief within Judaism" and therefore, that the law "does not create a denominational preference." to the laws of kashrut, then this conclusion might hold; however, there is not a clear consensus in some areas. For example, the Maryland law on its face would prohibit a Conservative Jew from advertising sturgeon or swordfish as kosher, despite his firm belief that such food is kosher according to the commands of God.

By attempting to resolve the meaning of this religious term, the Barghout court ignored one of the central principles of the Supreme Court's First Amendment jurisprudence: that "[i]ntrafaith differences ... are not uncommon among followers of a particular creed, and the judicial process is singularly ill equipped to resolve such differences in relation to the Religion Clauses." "kosher" means "Orthodox" is for the court itself to make a denominational preference by resolving a religious dispute over the meaning of "kosher" in favor of the Orthodox interpretation of the dietary laws.

Moreover, kosher food laws that rely on a denominational preference cannot withstand strict scrutiny. In Wilson, the court reasoned that the existence of an alternative provision that would achieve the state's goals without creating a denominational preference was fatal to the law under strict scrutiny. ${ }^{68}$ Even if preventing kosher food fraud is a compelling governmental interest, a denominational preference is invalid if there is a less burdensome means

at 129 NJ 141, 608 A2d 1353, 1359 (1992), cert denied as National Jewish Com'n on Law and Public Affairs (COLPA) $v$ Ran-Dav's County Kosher, Inc., 113 S Ct 1366 (1993).

ss $325 \mathrm{Md} 311,600$ A2d 841 (1992).

st Id at 847.

-7homas v Review Board, 450 US 707, 715 (1981).

as 920 F2d at 1287. 
of protecting that interest. As illustrated by the model law suggested in this Comment, ${ }^{68}$ there is such an alternative.

The First Amendment requires, at the very least, that a state that restricts use of the word "kosher" not define the term with reference to any particular sect of Judaism. Because of the disagreement over the meaning of "kosher," reference to a particular sect's interpretation necessarily favors that sect over others. The state may not avoid the proscription of denominational preferences by defining all of the requirements of orthodox Judaism rather than referring directly to the orthodox sect. ${ }^{70}$ Accordingly, any law similar to the New Jersey law, which selects a particular sect's definition of "kosher," must fail as a denominational preference.

Interestingly, a number of non-Orthodox Jewish organizations supported the New Jersey law. In an amicus curiae brief, several organized non-orthodox Jewish groups in New Jersey urged support of the law, despite the law's reference only to the Orthodox interpretation of the Jewish dietary laws. ${ }^{71}$ The groups did suggest, however, that the state should recognize sincerely-held variant beliefs.

Despite support from these various organizations, the New Jersey regulations still present a problem under the First Amendment. The Religion Clauses are generally unnecessary to protect well-organized, powerful religious groups:

Those groups whose beliefs are least foreign and least offensive to the mainstream, and those with the largest numbers and greatest visibility, will be better able to protect themselves than will the smaller, more unpopular groups .... [The bias in favor of mainstream religions] may not displease those who believe in the wisdom and virtue of majoritarian culture, but it-is not consistent with the original theory of the Religion Clauses. ${ }^{72}$

So See text accompanying notes 141-46.

${ }^{70}$ For instance, in Larson, the Court found a denominational preference even though the statute described a group of sects rather than naming the sects. Larson $v$ Valente, 456 US 228 (1982).

${ }^{21}$ Letter Brief of amici curiae of The New Jersey Association of Reform Rabbis, The Reconstructionist Rabbinical Association, The New Jersey Region of the Rabbinical Assembly, and The Rabbinical Council of New Jersey, 3 (Oct 22, 1990), in Ran-Dav's, 608 A2d 1353 (on file with U Chi L Rev).

${ }_{72}$ Michael W. McConneli, Religious Freedom at a Crossroads, 59 U Chi L Rev 115, 139 (1992). Compare United States v Carolene Products Co., 304 US 144, 152 n 4 (1938) ("prejudice against discrete and insular minorities may be a special condition, which tends seriously to curtail the operation of those political processes ordinarily to be relied upon to protect minorities, and which may call for a correspondingly more searching judicial in- 
It is the individual who does not agree with mainstream or common religious beliefs, or who disagrees with the positions of an organized group of which he is a member, who requires constitutional protection. Even in the absence of current disagreement over religious tenets, the law ought not establish today's consensus to the detriment of tomorrow's heresy.

B. The Lemon Test

Once beyond denominational preference, the Court proceeds to the Lemon test. A law challenged under the Lemon test must overcome three hurdles:

First the statute must have a secular legislative purpose; second, its principal or primary effect must be one that neither advances nor inhibits religion; finally, the statute must not foster "an excessive government entanglement with religion." "7s

The Lemon test has met substantial criticism. Professor McConnell refers to it as "the aptly named 'Lemon' test." $\mathrm{He}$ argues that the test "has an inherent tendency to devalue religious exercise."75 Despite the urging of the United States government, the Court in Lee $v$ Weisman ${ }^{78}$ declined an opportunity to reconsider the Lemon test. Lemon thus remains the law.

Even those laws that survive the threshold denominational preference inquiry must pass the Lemon test in order to survive under the Establishment Clause. Thus, while laws like those in

quiry"). But note that recently the Supreme Court has not given much weight to this argument. See generally Employment Division v Simith, 494 US 872 (1990), which held that generally applicable criminal laws that burden a religious practice need not be justified by a compelling governmental interest. The Court acknowledged that "leaving accommodation to the political process will place at a relative disadvantage those religious practices that are not widely engaged in," but preferred this to having "judges weigh the social importance of all laws against the centrality of all religious beliefs." Id at 890 .

A case decided this term, Church of Lukumi Babalu Aye, Inc. $v$ Hialeah, declined to overturn Smith. The plaintiff church observed the non-mainstream religion of Santeria; it challenged city ordinances banning animal sacrifices, which form part of its rites. The Court overturned the ordinances irrespective of Smith, because it reasoned that they were not neutral or of general application. 61 USLW 4587, 113 S Ct 2217 (1993).

7s Lemon v Kurtzman, 403 US 602, 612-13 (1971) (citations omitted).

74 McConnell, $59 \mathrm{U}$ Chi L Rev at 118 (cited in note 72).

75 Id at 128.

76 112 S Ct 2649, 2655 (1992) ("We can decide the case without reconsidering the general constitutional framework by which public schools' efforts to accomodate religion are measured .... The government involvement with religious activity in this case is pervasive, to the point of creating a state-sponsored and state-directed religious exercise in a public school."). 
New Jersey should be found unconstitutional before even reaching Lemon, the three-part Lemon inquiry controls for those laws, like Arizona's, that do not create denominational preferences.

\section{Secular purpose.}

The Court has done little to illuminate the secular purpose test since Lemon. What little guidance the Court has given can be summarized in a few sentences. First, the purpose test "asks whether government's actual purpose is to endorse or disapprove of religion." Second, the Court has noted that it has invalidated legislation under the purpose test only when "there was no question that the statute or activity was motivated wholly by religious considerations." 78 Since Lemon, the Court has invalidated state acts under the purpose prong only three times. ${ }^{79}$ Thus, the purpose prong presents little resistance to state action. ${ }^{80}$.

Not surprisingly, therefore, the secular purpose test has not been a problem for kosher food laws in state court challenges. States have uniformly justified their kosher food laws on the grounds that the laws are intended for general consumer protection, for both Jewish and non-Jewish consumers. As long as kosher food laws are motivated by such a secular objective, they will pass the least consequential of the Lemon prongs.

\section{Secular effect.}

Even if a government policy has a secular purpose, it should be struck down if "the essential effect of the action is to influence, either positively or negatively, the pursuit of a religious tradition or the expression of a religious belief." ${ }^{81}$ Although Lemon referred to a "primary effect," 82 the Court has later held that the determination of whether the advancement of religion is a "primary" effect of a state policy is not the proper inquiry: "We do not think that

${ }_{77}$ Edwards v Aguillard, 482 US 578, 585 (1987), quoting Lynch $v$ Donnelly, 465 US 668, 690 (1984) (O'Connor concurring).

${ }^{78}$ Lynch, 465 US at 680.

70 See Edwards, 482 US at 585-89 (state failed to identify "clear secular purpose" for statute mandating balanced teaching of evolution and creation science); Wallace $v$ Jaffree, 472 US 38, 56 (1985) (statute authorizing period of silence in public schools for meditation or prayer "had no secular purpose"); Stone v Graham, 449 US 39, 40-41 (1980) (statute requiring posting of Ten Commandments in public schools had no secular purpose).

${ }^{80}$ See McConnell, 59 U Chi L Rev at 145 (cited in note 72).

81 Laurence H. Tribe, American Constitutional Law § 14-10 at 1214 (Foundation Press, 2d ed 1988).

${ }_{82} 403$ US at 612. 
such metaphysical judgments are either possible or necessary."83 Instead, the inquiry is whether the state action "has the direct and immediate effect of advancing religion."84

In determining whether a policy directly and immediately advances religion, the Court has looked to the scope of the class of people or institutions affected by the policy. In Committee for Public Education $v$ Nyquist, ${ }^{85}$ the Court considered three financial aid programs for non-public schools adopted by the state of New York. ${ }^{86}$ Noting that approximately eighty-five percent of non-public schools were church-affiliated, the Court invalidated the programs on the grounds that their effect was to subsidize and advance the religious activities of sectarian schools. ${ }^{87}$

In Walz $v$ Tax Commission, ${ }^{88}$ the Court considered a property tax exemption for non-profit organizations. A property owner sought to enjoin the application of the exemption to the property of religious entities, on the grounds that such application would have the effect of a government subsidy to religion. The Court rejected the challenge, observing that

[the state] has not singled out one particular church or religious group or even churches as such; rather, it has granted exemption to all houses of religious worship within a broad class of property owned by nonprofit, quasi-public corporations which include hospitals, libraries, playgrounds, scientific, professional, historical, and patriotic groups. ${ }^{89}$

Rather than having a direct effect on religion, then, the policy in Walz was held to have an indirect or incidental effect. Because the benefit to religion was incidental to a larger program benefiting religious and non-religious groups of all sorts, the effect of the statute was not fatal under the Establishment Clause. The proper inquiry in the Walz case thus was not whether a grant of tax exemptions to churches directly advances religion, but whether the larger scheme of granting tax exemptions to non-profit organizations directly advances religion, given that some of the benefited organizations are religious.

\footnotetext{
ss Committee for Public Education v Nyquist, 413 US 756, 783 n 39 (1973).

84 Id.

ss 413 US 756 (1973).

s6 Id at 761-62.

${ }^{87}$ Id at 768, 774-94.

ss 397 US 664 (1970).

s9 Id at 673.
} 
The Court's approach to the effects test presents significant abstraction problems. At what level of generality should a court examine a state's kosher food law? Viewed in isolation, virtually any benefit conferred upon churches will appear problematic. In Walz, however, the Court suggested that a law affecting religious organizations can, in some circumstances, be viewed as part of a larger statutory scheme. Taken as a whole, this larger scheme may only incidentally affect religion, in which case the state law will pass the effects test. Neither the Constitution nor the Court's jurisprudence, of course, clearly indicates when such a broader perspective may be appropriate. Using Walz and Nyquist as guides, however, one can determine what kinds of statutes are more or less likely to survive an effects test challenge.

In the arena of kosher food law challenges, only the Ran-Dav's court has considered the effects test. The State defended its kosher food laws as a small part of a larger scheme of consumer protection laws with largely secular aims. To the court, the effects test distilled to the issue of whether "the laws of kashrut have become secular norms." Bo Because the laws of kashrut are necessarily religious, the court reasoned, the effect of kosher food laws "necessarily is to advance particular religious tenets."91

But the inquiry of the Ran-Dav's court cannot be right under the Walz and Nyquist formulations of the secular effect test. Although the laws of kashrut are undoubtedly religious principles, the primary effect of a kosher law may neverthless be secular in nature. To determine whether a kosher food law passes the effects test, therefore, courts must first consider the level of religious participation in the production and purchase of kosher food. Second, they must consider the proper level of generality for considering the effects of kosher food laws: are they to examine the kosher laws in isolation, or as part of a general consumer protection plan?

In Nyquist, the Court overturned the financial aid program for private schools because eighty-five percent of the private schools benefitted were religious. Just as some private schools are not religious, some consumers purchase kosher food for non-religious purposes. In general, the smaller the religious interest in kosher food, the less likely a kosher food law will fail the effects test.

Because of the significant religious interest in kosher food, laws relating specifically to kosher food arguably have the effect of advancing religion. That many Jewish groups argued in favor of

\footnotetext{
oo Ran-Dav's, 608 A2d at 1364.

22 Id.
} 
the laws in New Jersey also suggests that the laws advance religion. But this is not the end of the inquiry. If the state has created its kosher food regulations in an act separate from its other consumer protection laws, then the proper question for the court to ask is whether kosher food laws have the direct effect of advancing or inhibiting religion. However, if the state's kosher food laws are merely an integral part of a broader consumer protection scheme, the proper inquiry is whether this larger scheme, taken as a whole, impermissibly advances religion.

The result of the effects test will therefore hinge on how much the kosher food laws are integrated into a larger scheme of consumer fraud prevention. Using the placement of a kosher food law in the statute book to determine whether a kosher food law is merely part of a larger consumer protection plan is admittedly arbitrary. However, enforcement mechanisms might provide a more meaningful insight. To the extent that a statute creates a separate consumer fraud division which deals exclusively with kosher food fraud, the law will more likely fail the effects test. In contrast, if a state integrates its kosher food protections into a larger scheme of consumer protection with universal enforcement mechanisms, its program should be considered as a whole, with its effect on religion more attenuated.

\section{Entanglement.}

Impermissible entanglement of government and religion can take a number of forms. A government action is prohibited by the Establishment Clause if "it creates excessive administrative entanglement between church and state" or if "it turns over traditionally governmental powers to religious institutions." Tribe has noted that this administrative entanglement "sometimes arises when religious and public employees must work closely together in order to carry out the legislative plan."

In Larkin $v$ Grendel's Den, ${ }^{94}$ the Court considered a Massachusetts statute that gave churches and schools veto power over liquor licenses for establishments within 500 feet of their grounds. The Court overturned the statute because it delegated traditionally governmental powers to a religious institution: "[the law] substitutes the unilateral and absolute power of a church for the rea-

\footnotetext{
${ }^{92}$ Tribe, American Constitutional Law $\S 14-11$ at 1226 (cited in note 81).

93 Id at 1227 .

24 459 US 116 (1982).
} 
soned decisionmaking of a public legislative body."9s The Court also emphasized the excessive administrative entanglement involved, commenting that the statute "enmeshes churches in the processes of government."

The Court noted that the goals of the statute were in fact legitimate secular goals, but overturned the statute because "these valid secular objectives can be readily accomplished by other means." Among the alternatives, the Court cited "an absolute legislative ban on liquor outlets within reasonable prescribed distances from churches, schools, hospitals and like institutions" or holding hearings "for the views of affected institutions . . . where, without question, such views would be entitled to substantial weight." "98

What troubled the Court about the vesting of power in the religious groups was that the groups might use the power for religious, rather than secular ends: the power "could be employed for explicitly religious goals, for example, favoring liquor licenses for members of that congregation or adherents of that faith." tionally, "the mere appearance of a joint exercise of legislative authority by Church and State provides a significant symbolic benefit to religion in the minds of some by reason of the power conferred."100

The entanglement test presents the greatest hurdle for kosher food laws. The New Jersey regulations struck down in Ran-Dav's, for example, posed two entanglement problems. First, the head of the New Jersey Kosher Enforcement Bureau was an Orthodox Rabbi. ${ }^{101}$ Second, the Attorney General of New Jersey created the State Kosher Advisory Committee, which consisted of nine Orthodox rabbis and one Conservative rabbi. ${ }^{102}$

In Ran-Dav's, the court held that the New Jersey Attorney General's selection of rabbis to hold positions of criminal law enforcement violated the entanglement test of Lemon: "in this case, the existence of an Advisory Committee composed predominantly of orthodox rabbis underscores the theological or religious nature

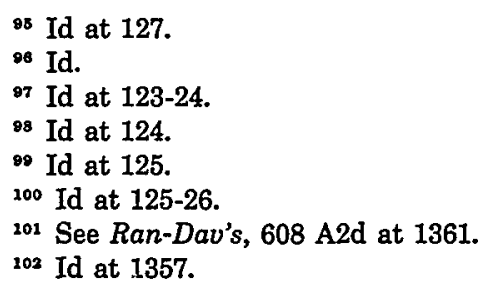


of the State's regulatory endeavors." 103 The court did not read the statute as creating a religious test for holding office on the committee, but observed that "because [the committee members] are being used by and for the State in their religious capacity to interpret and enforce state law, the religious and civil authority possessed by them is virtually indistinguishable."104

Formerly, California law granted traditionally governmental power to religious entities more explicitly. To determine the content of the Orthodox standards of kashrut, California created the office of Kosher Food Law Representative. ${ }^{105}$ In Glickman v Glas$n e r,{ }^{106}$ the court described the duties and required qualifications of the Representative. Although that court did not consider a challenge under the Establishment Clause to the creation of that position, an entanglement challenge under the Establishment Clause could easily be made out under the facts of the case.

The primary duty of the Representative, as stated in the State Personnel Board specifications, was to "carry out the statewide program of investigation and inspection in connection with the enforcement of the State Kosher Food Law."107 This included duties to "assure that [kosher] products have been properly identified, labeled, segregated, advertised, and otherwise handled in a manner consistent with orthodox Hebrew religious ritual and custom," and to "assist[] in the preparation of cases for prosecution." 108

Standing alone, these requirements do not present an entanglement problem. However, the California Personnel Board also required that the Kosher Food Law Representative be an "[o]rdained orthodox rabbi, in good standing with a recognized California or national rabbinical body and accredited to function in all spheres of the rabbinate" and that he have completed "theological studies for ordination as a rabbi at a recognized Jewish theological school."108

A law that requires officers with law enforcement power to be religious figures with religious training creates excessive entangle-

${ }^{103}$ Id at 1361, citing Lee $v$ Weisman, $112 \mathrm{~S} \mathrm{Ct} 2649$ (1992).

104 Id at 1364-65.

108 California eliminated the position of Kosher Food Law Representative in 1965 because of budget constraints. See Glasner $v$ Department of Public Health, 253 Cal App 2d 727, 61 Cal Rptr 415, 415 (1967).

106230 Cal App 2d 120, 40 Cal Rptr 719 (1964).

107 Cal State Personnel Board Specifications No 9034, reproduced in Glickman, 40 Cal Rptr at 721 n 2.

$108 \mathrm{Id}$.

100 Id. 
ment. ${ }^{110}$ But the state certainly should not disqualify religious figures from holding public office. Rather, courts should approach the problem by examining whether the rabbi in charge of enforcement is qualified for his position based on his capacity as a citizen or on his capacity as a rabbi. If he is more qualified for his position because of his status as a religious leader, and his religious training and knowledge are instrumental in his duties, then the creation of the office is suspect. Because California required that its enforcement representatives be ordained rabbis, in good standing with and accredited by a recognized rabbinical body, the state delegated the power of determining who is qualified for a particular governmental office wholly to private religious entities, in violation of Larkin. Moreover, the statute gave law enforcement power to a religious figure in his capacity as a religious figure.

In New Jersey, although the head of enforcement at the time of Ran-Dav's was a rabbi, "the previous Chief of Enforcement was neither a rabbi or an observant Jew."111 This provides some evidence that perhaps the head of enforcement was not an Orthodox rabbi by mandate. However, the character of the New Jersey law, which defines "kosher" with reference to Jewish law, suggests that the duties and requirements of the position are, in fact, religious.

With regard to an advisory committee of rabbis, Larkin's command is less clear. The Larkin Court recognized that the state could consider the views of a private religious body: "secular objectives" could be achieved "by ensuring a hearing for the views of affected institutions ... where, without question, such views would be entitled to substantial weight."112 The New Jersey statute struck down in Ran-Dav's, under which the Attorney General created the advisory committee comprised solely of rabbis, asked rabbis for advice on the interpretation of the rules of kashrut. The Committee acted in a purely advisory manner, and did not wield broad discretionary powers. However, the committee was an official government entity. The Larkin Court warned of "the mere appearance of a joint exercise of legislative authority by Church and

110 One might also challenge the religious training requirement in California on the grounds that it is a religious test for office. In Torcaso $v$ Watkins, 367 US 488 (1961), the Supreme Court declined to decide whether the religious test proscription of Article VI applies to the states. See id at 489 n 1 . However, the Court did "reaffirm that neither a State nor the Federal Government can constitutionally force a person to profess a belief or disbelief in any religion" as a prerequisite for holding government office under the Free Exercise Clause. Id at 495.

111 Ran-Dav's, $608 \mathrm{A2d}$ at 1369 (Stein dissenting).

112459 US at 124. 
State."11s Although the legislature and the Attorney General might have asked the rabbinate only for advice on how to draft and enforce the law effectively, Larkin would seem to prevent the creation of a standing governmental entity made up entirely of religious figures.

In the realm of entanglement, it is important to remember that Lemon prohibits only "excessive" entanglement. ${ }^{114}$ If the federal government hires a Roman Catholic Priest in his religious capacity as a military chaplain, it might not violate the entanglement prong of Lemon because the government cannot achieve its legitimate (and perhaps constitutionally required) goal of allowing soldiers to worship in a less entangling manner. In the kosher food arena, however, it is necessary to enlist the aid of rabbis only if the state chooses to draft its law in a way that incorporates religious standards. The alternative solution suggested in this Comment would require no entanglement of government with religion; therefore, the entanglement presented by the New Jersey and California regimes is likely excessive.

\section{Resolution of Religious Disputes}

Beyond denominational preference and the Lemon test, kosher food laws embroil courts in religious disputes. Judicial efforts to resolve purely religious disputes implicate both Establishment and Free Exercise concerns: a judicial resolution of a religious dispute "would simultaneously establish one religious view as correct for the organization while inhibiting the free exercise of the opposing belief." "1s The government may not "lend its power to one or the other side in controversies over religious authority or dogma."116

In Presbyterian Church v Mary Elizabeth Blue Hull Memorial Presbyterian Church, ${ }^{117}$ two local churches sought to withdraw from a general hierarchical church on the grounds that the general church had violated its constitution and religious doctrine. In resolving the property dispute that arose from the attempted withdrawal, the Court held that the First Amendment "commands civil courts to decide church property disputes without resolving under-

113 Id at 125 .

114403 US at 613.

116 Ronald D. Rotunda and John E. Nowak, Treatise on Constitutional Law: Substance and Procedure $\S 21.12$ at 572 (West, $2 \mathrm{~d}$ ed 1992).

116 Employment Division v Smith, 494 US 872, 877 (1990).

11393 US 440 (1969). 
lying controversies over religious doctrine."118 The Court also suggested a means of avoiding the problem in the future: "States, religious organizations, and individuals must structure relationships involving church property so as not to require the civil courts to resolve ecclesiastical questions." 110

The determination of what is kosher is a religious question. In United Kosher Butchers $v$ Associated Synagogues of Greater Boston, ${ }^{120}$ for example, the plaintiff attempted to show that the defendant had restrained trade by wrongfully refusing to accept plaintiff's guarantee that certain products were kosher. The court refused to pass on the question of whether plaintiff's certification of kashrut was correct: "Aside from the constitutional freedoms involved, this court is not qualified to decide and therefore must refuse to consider an issue which is so exclusively one of religious practice and conscience."121

In Ran-Dav's, the court recognized that by defining the term "kosher" as prepared in accordance with Orthodox requirements, the New. Jersey legislature had forced its state courts to resolve doctrinal disputes over the meaning of the word "Orthodox". The court noted that "no one practice can be called "the only true Judaism," and that "[d]isputes may occur infrequently, but when they do, they are ineluctably religious in tenor and content."122

In solving the kosher food problem, then, a state would be well-advised to frame its law in such a way to avoid altogether the possibility of its courts resolving religious doctrine in enforcing the law. If Judaism were a hierarchical religion, such that a single highest authority could speak authoritatively and conclusively on doctrinal matters, then the courts would not need to resolve any religious dispute-judges could merely ask the highest authority within Judaism for resolution of the problem. In Watson $v$ Jones, ${ }^{123}$ the Court recognized that "it is the essence of [hierarchical] religious unions, and of their right to establish tribunals for

118 Id at 449 .

110 Id.

120349 Mass 595, 211 NE2d 332 (1965).

121 Id at 334. See also Korn v Rabbinical Council of California, 148 Cal App 3d 491, 195 Cal Rptr 910, 914 (2d Dist 1983) ("we conclude that the determination of whether food is kosher is an ecclesiastical question unsuitable for adjudication in civil courts").

${ }_{122}$ Ran-Dav's, 608 A2d at 1362. For an example of a court resolving a religious dispute in the interpretation of a kosher food law, see People $v$ Gordon, 258 AD 421, 16 NYS2d 833, 834 (App Div 1940) (attachment of plumba to poultry as required by the United Rabbinate of New York is not part of the "Orthodox Hebrew religious requirements" for the purposes of New York's kosher food law).

12380 US (13 Wall) 679 (1871). 
the decision of questiops arising among themselves, that those decisions should be binding in all cases of ecclesiastical cognizance, subject only to such appeals as the organism itself provides for."124 Judaism, however, is not a hierarchical religion. There is no one practice that can be called "the only true Judaism." 125 Accordingly, deference to a hierarchical authority is not an option available to a court presented with a dispute over Jewish dietary practice. Because the Constitution prohibits courts from adjudicating religious disputes, a court cannot apply any law that defines the term "kosher" according to a religious standard. Judaism encompasses differences of opinion both within and among sects. Therefore, a definition of "kosher" as "prepared in accordance with orthodox requirements"128 requires the resolution of intra-sect disputes; a definition of "kosher" as "prepared under the traditional Hebrew rules and requirements or dietary laws"127 requires the resolution of inter-sect disputes. The Constitution prohibits both.

\section{FREE EXERCISE ${ }^{128}$}

A person sells "healing water" from the Dead Sea. The water actually comes from the California coast. The leader of a church starts the "Dare to be Rich" program, which offers fourfold returns on money given to God through the church. The "Dare to be Rich" program is nothing but a ponzi scheme. ${ }^{129} \mathrm{~A}$ restaurant advertises meat as having been koshered by roasting over an open flame. The chef has actually boiled the meat. All of these schemes are clearly fraudulent, yet the Free Exercise Clause prevents the state from punishing the exercise of religion. Can state and federal authorities punish these religious frauds without violating the Free Exercise Clause?

134 Id at 729.

13 Ran-Dav's, 608 A2d at 1362.

126 For statutes adopting similar language, see note 36.

127 Ariz Rev Stat Ann § 36-941(1) (West 1986).

128 Although purchasers of kosher foods who espouse minority interpretations of kashrut might mount a Free Exercise challenge to kosher food laws, this Comment addresses only the claims of purveyors of kosher foods.

${ }^{129}$ See United States v Rasheed, 663 F2d 843, 845-49 (9th Cir 1981). 


\section{A. United States v Ballard}

The Supreme Court answered this question in United States $v$ Ballard. ${ }^{130}$ In Ballard, defendants were convicted of mail fraud in connection with several religious representations associated with fundraising efforts. Among the representations was that defendants were divine messengers. ${ }^{131}$ The Supreme Court considered the propriety of the following jury instruction issued by the trial court: "Whether [the representations are] true or not is not the concern of this Court and is not the concern of the jury ... . The issue is: Did these defendants honestly and in good faith believe those things?"132 The Supreme Court upheld the jury instructions, noting that "we do not agree that the truth or verity of respondents' religious doctrines or beliefs should have been submitted to the jury .... [T] [Te First Amendment precludes such a course."13s

Religious fraud falls into two categories. The first category involves arguably religious statements that can be falsified by purely secular criteria. For instance, purely secular means can determine whether a vial of water has come from the Dead Sea. The second category involves religious statements that cannot be falsified by secular means. For instance, if defendant represents the vial of water as having been declared by God to be healing water, then the truth of the statement is a purely religious matter. No secular inquiry can determine whether God has made a declaration about the water. ${ }^{134}$

With religious claims of the second sort, Ballard mandates that the court look not to the truth of the statements involved, but only to the sincerity of the defendant's belief in the truth of the statements. If the defendant is sincere in his belief of the matters asserted, then no criminal liability can attach to his actions. Thus, Ballard acknowledges that the First Amendment "embraces the right to maintain theories of life and of death and of the hereafter which are rank heresy to followers of the orthodox faiths."135

A kosher food law can be framed in two ways. First, the law could require that the defendant knowingly violate the definition of "kosher" advanced by the state. Alternatively, the law could re-

\footnotetext{
130322 US 78 (1944).

131 Id at 79.

132 Id at 81.

193 Id at 86 .

194 For a general discussion of religious fraud and secular versus non-secular claims, see Stephen Senn, The Prosecution of Religious Fraud, 17 Fla St U L Rev 325 (1990).

${ }^{135}$ Ballard, 322 US at 86.
} 
quire that the defendant knowingly violate his own good-faith beliefs in the interpretations of his religious principles, even if his beliefs conflict with the state's position. Because the representation of food as kosher is a religious representation, Ballard mandates that the law be framed to require the defendant's violation of his own deeply-held religious beliefs.

All cases dealing with kosher food fraud acknowledge that a knowing misrepresentation with the purpose of deceiving the consumer is required to make out a case of fraud under the statutes. Recognizing the limits of Ballard, the New Jersey intermediate appellate court interpreted that state's statute to mean that "the State cannot and will not resolve whether any person's religious tenet is true, or even whether it is correct within the bounds of the person's own organized religion."136 This interpretation avoids the proscriptions of Ballard - that in cases of religious misrepresentation, the state may look only to the sincerity of the defendant's religious beliefs, and may not look to the truth or even the reasonableness of the defendant's convictions.

In Barghout, the court held that "vendors' who sincerely believe that their food products meet the kosher requirements would not violate the ordinance." ${ }^{137}$ However, the court upheld a denominational preference in favor of the Orthodox interpretation of the term "kosher." The court did not specify if a sincere belief that food is kosher according to Conservative Jewish standards would serve as a defense.

After Ballard, then, if a state defines "kosher," the state's definition can have no force when applied to one who has differing religious convictions about the meaning of the term. As discussed above, no state may define "kosher" according to the beliefs of any particular sect of Judaism. The state can avoid the denominational preference problem, as did the Arizona legislature, by defining "kosher" with reference to Judaism in general. However, even with such a definition, Ballard requires that the court look to a defendant's sincerely-held religious belief about what Judaism requires. If

${ }_{136}$ Ran-Dav's County Kosher, Inc. v State, 243 NJ Super 232, 579 A2d 316, 327 (Super App Div 1990), rev'd, 129 NJ 141, 608 A2d 1353 (1992), cert denied as National Jewish Comm'n on Law and Public Affairs (COLPA) v Ran-Dav's County Kosher, Inc., $113 \mathrm{~S} \mathrm{Ct}$ 1366 (1993). In overturning the lower court, the New Jersey Supreme Court rejected the Appellate Division's interpretation: "[M]erchants sincerely believing that their products are kosher could nevertheless be prosecuted under the regulations if the State believes that their products do not conform to the standards of Orthodox Judaism as the State defines and applies them." $608 \mathrm{~A} 2 \mathrm{~d}$ at 1359.

137325 Md 311, 600 A2d 841, 845 (1992). 
the court may look only to the sincerity, rather than the truth, of the defendant's beliefs, then the dispositive question is what the defendant sincerely believes to be kosher, not what the state-or what a majority of rabbis-deems to be kosher.

\section{B. Ballard after Employment Division v Smith}

The Supreme Court recently addressed the question of whether the First Amendment requires states to provide religious exemptions to generally applicable laws. In Employment Division, Department of Human Resources of Oregon v Smith, ${ }^{\mathbf{1 3 8}}$ the Court considered a law that denied unemployment benefits to employees discharged for ingesting peyote. The employees argued that the Constitution mandates an exception to such a law for those who use peyote for religious purposes. The Court held that although "a nondiscriminatory religious-practice exemption is permitted ... it is [not] constitutionally required."139

Smith does not weaken Ballard's application to religious fraud, however. In Ballard, the defendants did not claim, nor did the Court grant, a religious exemption from generally applicable fraud laws. The Ballard Court never held that a person with a strong religious conviction that fraud is desirable must be allowed to defraud others. Instead, Ballard held that no fact-finder could look to the truth of religious representations to make out a case of fraud. ${ }^{140}$

Smith therefore does not erase the protections of Ballard. In the arena of kosher food laws, the state may attempt to define "kosher" without preferring one sect of Judaism over any other; however, the state may not scrutinize the truth of the defendant's definition through the lens of the state's definition. It may look only to the defendant's sincere belief that his product adheres to the laws of kashrut. This limitation on the prosecution of kosher food fràd does not mandate that anyone be exempted from prosecution for defrauding others; instead it defines the limits of the evidence available to the prosecution to show the falsity of an allegedly fraudulent statement.

\footnotetext{
138 494 US 872 (1990).

130 Id at 890.

${ }^{140} 322 \mathrm{US}$ at 86.
} 


\section{The Solution to the Kosher Food Regulation Problem}

In 1990, Representative Steven Solarz proposed an amendment to the Food, Drug and Cosmetic Act entitled the "Public Disclosure of Religious Dietary Certification Act."141 This legislation was to apply to any food product bearing a symbol "which may reasonably interpreted by consumers to imply that the food has been certified by a certifying authority as conforming to religious dietary standards."142 The law would require the producer of any such food product to file a statement disclosing the name of the product and the name of the certifying authority. A seller could be punished for filing a false statement regarding a certifying authority. The proposed law would not, however, "authorize the Secretary [] to determine whether a certifying authority is appropriately qualified to serve in such capacity, or [] to determine whether or not a food that has been certified by a certifying authority in fact conforms to religious dietary standards." 143 Had the bill become law, the new law would have avoided constitutional problems: the law requires merely that a seller tell the truth about whether his food is certified as kosher by an independent organization. Moreover, the law does not permit a determination of the "truth" of a religious conviction.

As amici curiae in Ran-Dav's, a number of Jewish groups, including representatives for Reform and Reconstructionist groups, argued that the state could define the term "kosher," but that the state should allow sincerely-held variant beliefs. However, the groups argued that disclosure should be required if the beliefs of a purveyor diverge from what the groups saw as the "single historical standard of kosher determination."144

A system similar to that introduced as federal legislation could constitutionally achieve a state's goal of preventing consumer fraud. Such a statutory scheme would combine the power of a market solution with mandated disclosure of standards of kashrut.

Because the Constitution dictates that the state cannot judge the truth of religious statements-and a statement that food is kosher is inherently a religious one-the state could effectively deter fraud by requiring that anyone representing a food product as kosher make secular claims about the grounds upon which he be-

\footnotetext{
141 HR 5447, 101st Cong, 2d Sess (Aug 2, 1990).

${ }^{142}$ See id at $\S 3(1)$.

${ }^{143}$ Id at $\S 4(6)$.

${ }^{144}$ Letter Brief of amici curiae in Ran-Dav's, 608 A2d 1353 (1992) (cited in note 71).
} 
lieves the product to be kosher. ${ }^{145}$ These claims could include: "The production of this food was supervised by the Kosher Supervision Service" (a private kosher certification authority) or "This meat was soaked and salted after slaughter." In addition, in order to prevent fraudulent supervision, the state could require the supervising organizations to disclose, either in a public filing or on food packaging, the standards they employ in making their certification decisions. ${ }^{148}$ The state could verify all of these statements without appealing to religious principles. If a purveyor knowingly and falsely claimed that his product was overseen by the Kosher Supervision Service, there would be no First Amendment problem with prosecuting him for fraud or enforcing the law of trademark infringement.

Under this scheme, the state could prosecute a purveyor for kosher food fraud only if the food did not conform to the individual's stated definition of "kosher"; the purveyor knew that the food did not so conform; and the purveyor intended to deceive consumers with the misrepresentation. Likewise, the state would be able to prosecute the supervising agency for fraud if it knowingly certified as "kosher" purveyors who did not satisfy the organization's stated definition. The proposed scheme focuses on ordinary secular claims rather than religious claims, and thereby avoids questions of religious sincerity, which are generally difficult to adjudge.

To avoid an effects challenge, the law should be integrated into a larger plan of consumer protection. Consumer protection laws prevent an appliance manufacturer from advertising that her product is endorsed by the Underwriters Laboratories when it is not; so too the law could prevent a butcher from representing food as supervised by the Kosher Supervision Service when it is not. ${ }^{147}$ The law prevents a grocer from advertising "pasteurized" milk when the milk is not pasteurized; so too the law could prevent a restaurateur from advertising a meat as koshered by roasting over an open flame when the meat is fried.

Such a scheme would also avoid any problems of entanglement. If the state need not define the term "kosher," it need not

\footnotetext{
148 This suggestion is similar to an alternative suggested in Ran-Dav's, 608 A2d at 1366 ("The regulation could require those who advertise food products as 'kosher' to disclose the basis on which the use of that characterization rests.").

${ }^{146}$ For example, such a disclosure might read: "In order to be certified by the Kosher Supervision Service, a purveyor must sell only meat that was soaked and salted after slaughter and to submit his products to random inspection by the Service to ensure compliance."

147 See Ran-Dav's, 608 A2d at 1366.
} 
enlist religious experts to interpret the laws of kashrut. If prosecuting kosher food fraud involved merely verifying whether the preparation of food was overseen by a particular private organization or was performed according to specified methods, then no expert religious opinion would be necessary-the ordinary prosecutorial tools of the state would suffice. Private rabbinical organizations allow the use of their symbols through contract; any dispute between a purveyor of kosher food and such an organization could be resolved as a contractual dispute, with matters of religious faith left to the parties to the contract to resolve. The involvement of religious figures and institutions would remain in the private sphere. The religious content of statements made about kosher food would be relegated to the relationship between the purveyor and a certifying body, or, in the case where a purveyor chooses not to enlist a certifying body, to the individual himself.

This system is attractive because the means to implement it are already well-developed. Many private organizations currently certify food as kosher. By placing the seal of one of these organizations on its packaging, a producer essentially states that the food is kosher according to that organization's definition. Under the proposed disclosure system, the purveyors of kosher food would continue to rely on certification by private certification authorities as a signal to customers.

The parties to kosher food certification contracts must be careful to structure their relations in such a way to avoid the necessity of resolution of religious disputes in possible legal actions for breach. As noted in Section II.C, the Court has suggested that "States, religious organizations, and individuals" must order their relations "so as not to require the civil courts to resolve ecclesiastical questions." 148 This caveat applies with equal force to a kosher food purveyor's drafting of a contract with a kosher food certification authority. For instance, one California court faced with an allegation of wrongful refusal to certify a food product as kosher refused to adjudicate the issue. ${ }^{149}$

A contract that would avoid the possibility of courts being asked to resolve religious disputes could specify all preparation

113 Presbyterian Church v Mary Elizabeth Blue Hull Memorial Presbyterian Church, 393 US 440, 449 (1969).

149 Korn v Rabbinical Council of California, 148 Cal App 3d 491, 195 Cal Rptr 910, 912 (2d Dist 1983) ("we conclude that the determination of whether food is kosher is an ecclesiastical question unsuitable for adjudication in civil courts"); United Kosher Butchers v Associated Synagogues of Greater Boston, 349 Mass 595, 211 NE2d 332, 334 (1965) (refusing to consider "an issue which is so exclusively one of religious practice and conscience"). 
and handling procedures necessary to acquire certification. However, because Jewish dietary law is complex, enumeration of all preparation requirements could be unduly cumbersome. Therefore, the contract could instead include terms that would require certification of the purveyor's food as kosher unless the certifying authority believed, in good faith, that the food was not kosher according to its own definition of kashrut. In an action for breach of contract based on wrongful refusal to certify food as kosher, the court would need not consider whether the food was kosher. Rather, the court would look to the sincerity of the certifying authority's belief in the fitness of the food in dispute. This inquiry would be the civil analogue of Ballard-an inquiry into the sincerity of belief rather than the truth of belief.

\section{Conclusion}

Any kosher food statute that will survive constitutional challenge must avoid the problems discussed above. First, the statute must not favor one sect of religion over others. Second, the statute must not directly advance religion. Third, the law must not create an entanglement of government and religion. Fourth, the law must not require courts to resolve religious disputes. And finally, the law must not operate in such a way as to call into question the truth of the defendant's religious claims.

In order to regulate kosher food constitutionally, then, a state must not define the term "kosher" at all. Because the term is essentially a religious one, courts are not fit to resolve disputes over its meaning. Moreover, if the state defines the term, and then holds purveyors of kosher food who sincerely disagree to that standard, it violates the principles of Ballard.

The kosher food laws in most states thus violate the Constitution. Laws that select a particular sect's definition of "kosher" as the state's definition fail as denominational preferences. Those that select a definition without reference to a particular sect's views fail on Free Exercise grounds. In order to protect its consumers from kosher food fraud, then, no state may go further than to require the seller to disclose his certifying organization or the procedures followed in preparing his food. 